\title{
Article \\ High-Throughput Cell Concentration Using A Piezoelectric Pump in Closed-Loop Viscoelastic Microfluidics
}

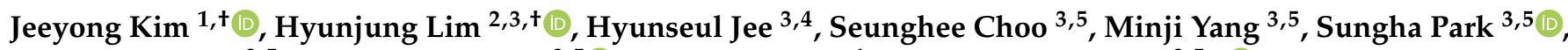 \\ Kyounghwa Lee ${ }^{3,5}$, Hyoungsook Park ${ }^{3,5}{ }^{-}$, Chaeseung Lim ${ }^{1, *}$ and Jeonghun Nam ${ }^{3,5, * \mathbb{C}}$ \\ 1 Department of Laboratory Medicine, College of Medicine, Korea University, Seoul 08307, Korea; \\ emperorjy@naver.com \\ 2 Department of Obstetrics and Gynecology, College of Medicine, Korea University, Seoul 08307, Korea; \\ hyunjunglim.email@gmail.com \\ 3 Artificial Intelligence(AI)-Bio Research Center, Incheon Jaeneung University, Incheon 21987, Korea; \\ jhs603@korea.ac.kr (H.J.); tmdg12887@gmail.com (S.C.); chymj12172947@gmail.com (M.Y.); \\ m000855@jeiu.ac.kr (S.P.); lee12042@jeiu.ac.kr (K.L.); muni24@jeiu.ac.kr (H.P.) \\ 4 Department of Medical Sciences, Graduate School of Medicine, Korea University, Seoul 08307, Korea \\ 5 Department of Song-do Bio Engineering, Incheon Jaeneung University, Incheon 21987, Korea \\ * Correspondence: malarim@korea.ac.kr (C.L.); jhnam77@gmail.com (J.N.); Tel.: +82-2-2626-1514 (C.L.); \\ +82-32-890-7515 (J.N.) \\ + These authors equally contributed to this work.
}

\section{check for} updates

Citation: Kim, J.; Lim, H.; Jee, H.; Choo, S.; Yang, M.; Park, S.; Lee, K.; Park, H.; Lim, C.; Nam, J. High-Throughput Cell Concentration Using A Piezoelectric Pump in Closed-Loop Viscoelastic Microfluidics. Micromachines 2021, 12, 677. https://doi.org/10.3390/ mi12060677

Academic Editor:

Nam-Trung Nguyen

Received: 23 May 2021

Accepted: 7 June 2021

Published: 9 June 2021

Publisher's Note: MDPI stays neutral with regard to jurisdictional claims in published maps and institutional affiliations.

Copyright: (c) 2021 by the authors. Licensee MDPI, Basel, Switzerland. This article is an open access article distributed under the terms and conditions of the Creative Commons Attribution (CC BY) license (https:// creativecommons.org/licenses/by/ $4.0 /)$.
Abstract: Cell concentration is a critical process in biological assays and clinical diagnostics for the pre-treatment of extremely rare disease-related cells. The conventional technique for sample preconcentration and centrifugation has the limitations of a batch process requiring expensive and large equipment. Therefore, a high-throughput continuous cell concentration technique needs to be developed. However, in single-pass operation, the required concentration ratio is hard to achieve. In this study, we propose a closed-loop continuous cell concentration system using a viscoelastic non-Newtonian fluid. For miniaturized and integrated systems, two piezoelectric pumps were adopted. The pumping capability generated by a piezoelectric pump in a microfluidic channel was evaluated depending on the applied voltage, frequency, sample viscosity, and channel length. The concentration performance of the device was evaluated using $13 \mu \mathrm{m}$ particles and white blood cells (WBCs) with different channel lengths and voltages. In the closed-loop system, the focused cells collected at the center outlet were sent back to the inlet, while the buffer solution was removed to the side outlets. Finally, to expand the clinical applicability of our closed-loop system, WBCs in lysed blood samples with $70 \%$ hematocrit and prostate cancer cells in urine samples were used. Using the closed-loop system, WBCs were concentrated by $\sim 63.4 \pm 0.8$-fold within $20 \mathrm{~min}$ to a final volume of $160 \mu \mathrm{L}$ using $10 \mathrm{~mL}$ of lysed blood sample with $70 \%$ hematocrit $(\sim 3 \mathrm{cP})$. In addition, prostate cancer cells in $10 \mathrm{~mL}$ urine samples were concentrated by $\sim 64.1$-fold within $\sim 11$ min due to low viscosity $(\sim 1 \mathrm{cP})$.

Keywords: closed-loop; concentration; piezoelectric pump; viscoelastic fluid; high-throughput

\section{Introduction}

In biological assays and clinical diagnostics, sample preconcentration is a critical process for the pre-treatment of extremely rare disease-related cells to improve detection sensitivity [1]. Conventionally, centrifugation is the most widely used method to enrich cells into smaller volumes. However, centrifugation has several limitations. First, the centrifugation process is a batch operation, requiring expensive and bulky apparatuses, and which is inadequate for use at the point of care. Second, cells can be physically damaged due to the mechanical shear force exerted on the cells during centrifugation [2,3]. Next, a large volume reduction requires multiple centrifugation steps in a series. In particular, in rare cell applications (for example, circulating tumor cells, fungus, and fetal cells in 
maternal blood), the final resuspension volume can be a microliter-scale volume to achieve an appropriate cell concentration [1]. However, during multiple steps, manual transfer steps are required, and sample loss can occur.

To address the above-mentioned limitations of the centrifugation process for cell concentration, microfluidic tools for cell concentration have been developed using dielectrophoretic [4,5], acoustic [6-8], gravitational [1], and hydrodynamic forces [9]. Recently, viscoelastic non-Newtonian microfluidics have gained much attention, owing to intrinsic nonlinear elastic forces in pressure-driven flows of polymer solutions [10,11]. The main advantages of viscoelastic microfluidics are the wide usable range of flow rates and lateral migration of particles/cells in a simple straight microchannel [12]. Based on these advantages, viscoelastic non-Newtonian fluids have been used for particle/cell-focusing [11,13,14], sizebased particle/cell separation [15-19], and shape-based cell particle/cell separation [20]. More recently, a viscoelastic microfluidic device for a sheathless, continuous concentration of white blood cells (WBCs) was proposed [21]. Using the viscoelastic cell-focusing technique, WBC samples with extremely low concentrations could be concentrated 18-fold with high throughput ( $350 \mu \mathrm{L} / \mathrm{min})$.

For further enhancement of the concentration performance of the single-pass operation, a closed-loop operation of the microfluidic channel was introduced [7,22,23]. In a singlepass operation, the concentration performance was determined by the channel design or suction flow control [24]. However, by feeding the concentrated stream of target cells continuously back to the sample inlet through a closed feedback loop, the concentration performance can be improved.

To generate a flow in a microfluidic chip, an external pumping system is required. Conventionally, commercialized pumps, including a syringe pump and a peristaltic pump, have been used, with the advantages of flow stability and wide flow rate range [25,26]. However, these are not suitable for the miniaturization and integration of microfluidic devices owing to their bulky size [27]. The use of piezoelectric pumps can address these limitations, with the advantages of small size, low noise, and low power consumption. Previously, the piezoelectric pump was used for flow actuation in microfluidic channels [27-29]. To the best of our knowledge, this is the first study to use piezoelectric pumps for microparticle/cell manipulation.

In this study, we propose a closed-loop viscoelastic microfluidic device to achieve a high concentration ratio of initially rare target cells. In addition, the sheathless viscoelastic concentration technique facilitated the use of parallel channels to improve the device throughput. Miniature and lightweight piezoelectric diaphragm pumps were used for flow actuation in cell concentration applications owing to the reduced flow resistance by using a device with multiple parallel channels. The performance of the piezoelectric pump in the microchannel was evaluated depending on the frequency, applied voltage, channel length, and viscosity of the working fluid. Next, we examined the flow characteristics of $13 \mu \mathrm{m}$ particles and WBCs to determine the optimal flow conditions for cell concentration. Finally, as examples of clinical utilization of the closed-loop viscoelastic cell concentration system, a lysed blood sample was used to enrich the WBCs for the quality control of the blood transfusion, and the prostate cancer cell line was used for the diagnosis of prostate cancer using urine samples.

\section{Materials and Methods}

\subsection{Device Fabrication}

A polydimethylsiloxane (PDMS) microchannel was fabricated using soft-lithography techniques with a replica mold. The mold was fabricated using an SU-8 negative photoresist (MicroChem, Newton, MA, USA) patterned on a silicon wafer. A 10:1 mixture of the PDMS base and curing agent (Sylgard 184, Dow Corning, Midland, MI, USA) was mixed, cast over the replica mold, degassed in a vacuum chamber, and thermally cured in an oven for $1 \mathrm{~h}$ at $80^{\circ} \mathrm{C}$. The cured PDMS channels were peeled off from the mold and bonded on a glass slide with oxygen plasma (CUTE, Femto Science, Hwaseong, Korea). 
The high-throughput cell concentration device consisted of four microchannels, each $60 \times 125 \mu \mathrm{m}(\mathrm{W} \times \mathrm{H})$ with a high aspect ratio $(\mathrm{AR}=$ height/width). The device includes a parallel arrangement of channels with a common single inlet and two outlets for each channel. The lengths of the main channel were 1,2, and $3 \mathrm{~cm}$ to determine the optimal length of the main channel after the evaluation of the flow characteristics of cells in the microfluidic device. The width of the expansion region was designed to be $200 \mu \mathrm{m}$ for monitoring the flow characteristics, and the widths of the outlet trifurcation channels connected to the expansion region were 150,100 , and $150 \mu \mathrm{m}$, respectively.

A plastic jig was fabricated by a three-dimensional (3D) printing technique using a 3D printer (ProJet 3510 HD, 3D systems, Rock Hill, SC, USA) to hold a PDMS microchannel device, two commercial $50 \mathrm{~mL}$ conical tubes as the sample and waste chamber, two piezoelectric pumps, and a needle valve.

\subsection{Cell Culture}

The prostate cancer cell line DU-145 was obtained from the Korean Cell Line Bank (Seoul, Korea). DU-145 cells were cultured in Falcon T-25 cell culture flasks in 89\% RPMI1640 with L-glutamine (300 mg/L), $25 \mathrm{mM} \mathrm{HEPES,} \mathrm{and} 25 \mathrm{mM} \mathrm{NaHCO}_{3}$ containing $10 \%$ fetal bovine serum and $1 \%$ penicillin-streptomycin (all Gibco). Cell culture flasks were kept in a $5 \% \mathrm{CO}_{2}$-controlled incubator at $37^{\circ} \mathrm{C}$. Cells were prepared for the experiment once $70 \%$ confluent by removing the medium and washing the culture flask with $2 \mathrm{~mL}$ of $0.05 \%$ Trypsin-EDTA ( $1 \times$, Gibco, Thermo Fisher, Waltham, MA, USA). Next, 4 mL of pre-warmed RPMI was added to neutralize trypsin. After detachment, the cells were spun at $1000 \mathrm{rpm}$ for $3 \mathrm{~min}$ and the pellet was used. Cells were passaged every third day.

\subsection{Sample Preparation}

First, $0.1(w / v) \%$ hyaluronic acid (HA) sodium salt (357 kDa, Lifecore Biomedical, Chaska, MN, USA) was prepared in phosphate-buffered saline as a viscoelastic nonNewtonian fluid. The high shear viscosity $(\eta \infty)$ and relaxation time $(\lambda)$ of the solution were measured as $0.89 \mathrm{mPa} \cdot \mathrm{s}$ and $0.25 \mathrm{~ms}$, respectively [30]. Fluorescence polystyrene particles $13 \mu \mathrm{m}$ in diameter were used as an analog to WBCs. The particles were suspended in $0.1 \%$ HA solution at approximately $1 \times 10^{5}$ particles $/ \mathrm{mL}$.

For sample preparation, single-donor human whole blood and pooled human urine (Innovative Research, Inc., Novi, MI, USA) were used. In brief, by removing the plasma after centrifugation at $800 \times g$ for $10 \mathrm{~min}$, blood samples with a hematocrit of $70 \%$ were prepared to simulate the packed red blood cells for blood transfusion. Thereafter, $1 \mathrm{~mL}$ of the prepared blood sample was mixed with $7 \mathrm{~mL}$ of $1 \times$ BD FACS lysis buffer (BD Biosciences, Franklin Lakes, NJ, USA), $1 \mathrm{~mL}$ of $1 \times$ SYBR Green, and $1 \mathrm{~mL}$ of $1(w / v) \%$ HA solution, which had a final concentration of $0.1(w / v) \%$ HA solution in a total volume of $10 \mathrm{~mL}$. The number of WBCs was counted manually using a hemocytometer. For the final application of the closed-loop viscoelastic concentration system, cultured DU-145 cells were spiked in $9 \mathrm{~mL}$ of pooled human urine sample and mixed with $1 \mathrm{~mL}$ of $1(w / v) \% \mathrm{HA}$ solution. The final concentration of DU-145 cells was $1.5 \times 10^{3}$ cells $/ \mathrm{mL}$ in $0.1(w / v) \%$ HA solution.

\subsection{Experimental Procedure}

The injection and suction flow rates were controlled by two piezoelectric micropumps (SDMP320, Takasago, Tokyo, Japan). The piezopump uses a piezodisc to actuate a COC diaphragm and ethylene propylene diene monomer check valves to generate a directed flow [31]. Two piezoelectric micropumps were controlled simultaneously by using a piezoelectric micropump controller (MPC-200B-EU, Takasago), which modulated the frequency and voltage applied to the pump. The input voltage to the controller was 5 VDC, and the output voltage from the controller ranged from 60 to $300 \mathrm{~V}$, which was applied to the piezoelectric pump. Additionally, a micro needle valve (MNV series, Takasago) was used to regulate the flow rate in detail. 
To connect the microfluidic channel, two piezopumps and reservoirs, and a Tygon tube with an inner diameter of $0.51 \mathrm{~mm}$ were used. The total length of the Tygon tube was approximately $400 \mathrm{~mm}$, which affects the dead volume of the fluidic system.

During the experiment, particles/cells flowing in the microchannel were monitored using an inverted microscope (CKX41, Olympus, Tokyo, Japan) with a high-speed camera (V611, Phantom, St. Louis, MI, USA) and a fluorescent camera (CS230B, Olympus, Tokyo, Japan).

\section{Results}

A schematic of the proposed device for high-throughput cell concentration using closed-loop viscoelastic fluid is depicted in Figure 1. As shown in the schematic in Figure 1, the device consisted of four parallel microfluidic channels with a high AR, which has one common inlet and two outlets for each channel. At the inlet, the initial sample containing cells at low concentration was injected into the microchannel as randomly distributed (Figure 1a). In the viscoelastic fluid, the elastic force $\left(F_{e}\right)$ induced by the non-dimensional distribution of the first normal stress difference $\left(N_{1}\right)$ affects the lateral migration of the suspended cells toward the channel center (Figure 1b) $[11,32,33]$. The channel width was designed to make the blockage ratio $(\beta=a / W$, where $a$ is the cell diameter and $W$ is the channel width) of the cells higher than $0.1(\beta \geq 0.1)$ to focus the cells at the center plane of the microchannel. Focused cells were collected from the four center outlets connected to a single outlet A (Figure 1c). At outlet B, the suction flow rate was controlled by a piezoelectric pump and a micro needle valve to remove the additional suspending medium and enhance the concentration factor of cells at outlet A. Through the closed-loop system, the collected sample at outlet A was recirculated to the inlet of the microchannel and the cells were finally recovered at a higher concentration factor at outlet A. Figure 1d shows a photograph of the fabricated closed-loop system for high-throughput viscoelastic cell concentration containing two PZT pumps, a controller, two reservoirs, a micro needle valve, and a PDMS channel.
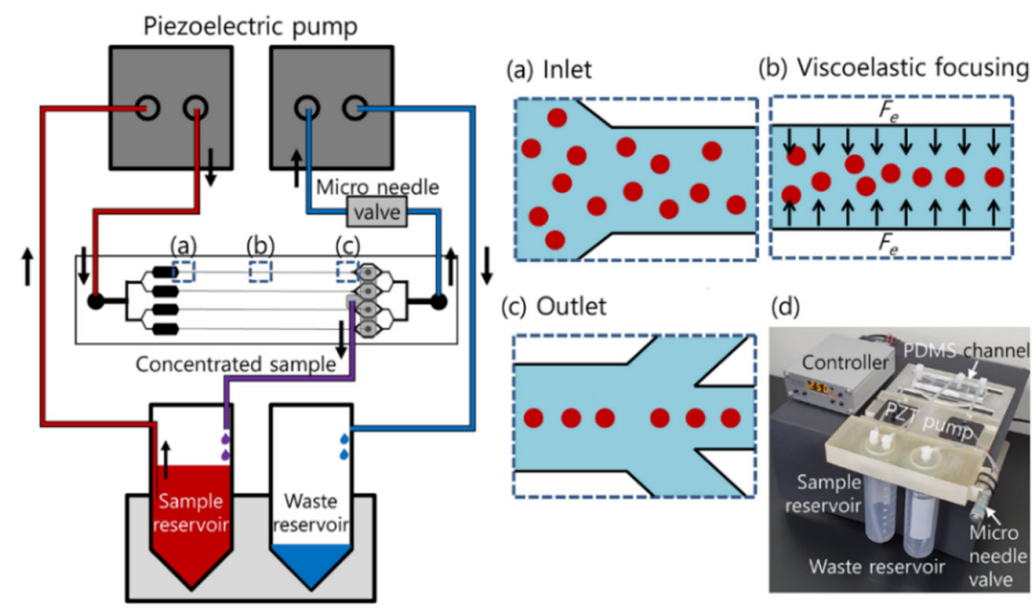

Figure 1. Schematic of the closed-loop system for high-throughput viscoelastic cell concentration. The 3D-printed jig contains a microfluidic device with four parallel channels, two piezoelectric pumps, a sample reservoir, a waste reservoir, and a micro needle valve. (a) Cell suspension in a viscoelastic fluid was randomly introduced to the inlet. (b) Due to the elastic force, cells were focused in the center of the microchannel. (c) At the outlet, tightly focused cells were collected from the center outlet and the additional medium was removed to the side outlets. (d) Fabricated closed-loop system for high-throughput viscoelastic cell concentration.

To apply a piezoelectric micropump in the device, the applied frequency- and voltagedependent flow rates were evaluated. At the microscale, the flow resistance increases drastically because a high surface force becomes predominant over the body force. In 
the microfluidic flow, the flow rate decreases owing to the pressure drop induced by the flow resistance. The flow resistance of the microchannel can be determined by the channel dimension and solution viscosity, as shown below.

$$
R=\frac{128 \eta L}{\pi D_{h}^{4}}
$$

Here, $\eta, L$, and $D_{h}$ refer to the fluid viscosity, channel length, and hydraulic diameter of the channel, respectively. With the fixed solution viscosity, the flow resistance of the microchannel is proportional to the channel length [34]. Therefore, Figure 2a shows the frequency-dependent flow rates in our system with different flow resistances. The flow resistances were calculated using microchannels with a width of $60 \mu \mathrm{m}$, height of $125 \mu \mathrm{m}$, and different lengths $(1,2$, and $3 \mathrm{~cm})$ as $4.96 \times 10^{11}, 9.92 \times 10^{11}$, and $1.48 \times 10^{12} \mathrm{~Pa} \cdot \mathrm{s} \cdot \mathrm{m}^{-3}$. The flow rate was measured by a flow sensor (SLI, Sensirion, Staefa, Switzerland) with or without a microchannel. Without a microchannel, the piezoelectric pump-induced flow rate increased with the frequency from $7 \mathrm{~mL} / \mathrm{min}$ at $10 \mathrm{~Hz}$ to $34 \mathrm{~mL} / \mathrm{min}$ at $60 \mathrm{~Hz}$ at the macroscale, which was in agreement with the specifications provided by the manufacturers. With the microchannels, the flow rates were much lower than $3 \mathrm{~mL} / \mathrm{min}$, owing to the flow resistance of the microchannel. As the channel length increased, the flow rate decreased. With a $3 \mathrm{~cm}$-long channel $\left(R=1.48 \times 10^{12} \mathrm{~Pa} \cdot \mathrm{s} \cdot \mathrm{m}^{-3}\right)$, the flow rate increased from $1.9 \mathrm{~mL} / \mathrm{min}$ at $10 \mathrm{~Hz}$ to $2.9 \mathrm{~mL} / \mathrm{min}$ at $40 \mathrm{~Hz}$. With microchannels of 2 $\left(R=9.92 \times 10^{11} \mathrm{~Pa} \cdot \mathrm{s} \cdot \mathrm{m}^{-3}\right)$ and $1 \mathrm{~cm}$ lengths $\left(R=4.96 \times 10^{11} \mathrm{~Pa} \cdot \mathrm{s} \cdot \mathrm{m}^{-3}\right)$, the flow rate decreased to 0.9 and $0.6 \mathrm{~mL} / \mathrm{min}$, respectively. These flow rates were adequate for use in the microfluidic device for viscoelastic concentration.

(a) Fixed voltage $250 \mathrm{~V}$
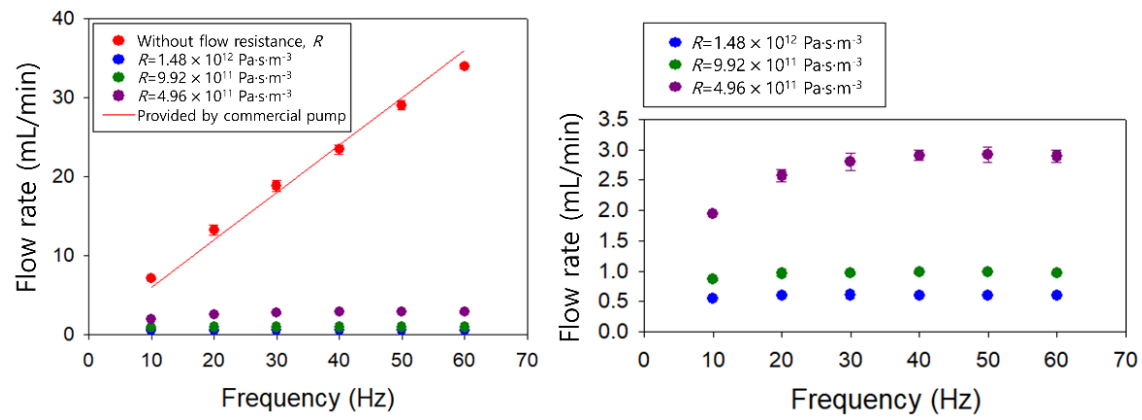

(b) Fixed frequency $40 \mathrm{~Hz}$
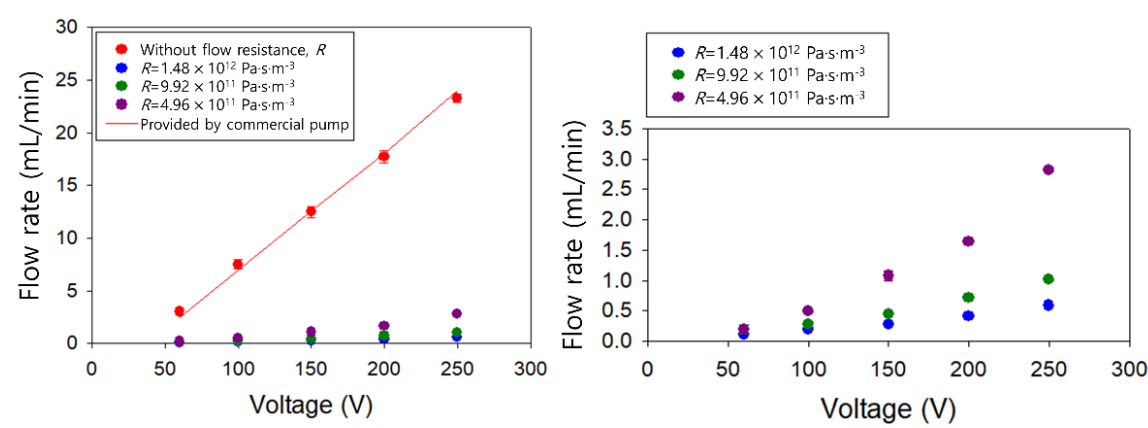

Figure 2. Evaluation of flow rates generated by a piezoelectric pump depending on (a) the frequency at the fixed voltage of $250 \mathrm{~V}$ and (b) the applied voltage at the fixed frequency of $40 \mathrm{~Hz}$ without/with 1,2 , and $3 \mathrm{~cm}$-long microchannels with different flow resistances of $4.96 \times 10^{11}, 9.92 \times 10^{11}$, and $1.48 \times 10^{12} \mathrm{~Pa} \cdot \mathrm{s} \cdot \mathrm{m}^{-3}$.

Figure $2 \mathrm{~b}$ shows the applied voltage-dependent flow rates at a fixed frequency of $40 \mathrm{~Hz}$. Without flow resistance of the microchannel, the flow rate increased from $3 \mathrm{~mL} / \mathrm{min}$ at $60 \mathrm{~V}$ to $23 \mathrm{~mL} / \mathrm{min}$ at $250 \mathrm{~V}$. This is in agreement with the specifications of the manufacturer. 
For all cases, as the applied voltage increased, the flow rate increased. At an applied voltage of $250 \mathrm{~V}$, the flow rates induced in microchannels of 1,2 , and $3 \mathrm{~cm}$ were $2.8,1$, and $0.6 \mathrm{~mL} / \mathrm{min}$, respectively.

The detailed values of the flow rates and the calculated non-dimensional numbers under the different voltages in the different-length channels are listed in Table 1. Nondimensional numbers were defined to evaluate the flow characteristics of the particles in the viscoelastic flow. Reynolds number $(R e)$ describes the ratio of the inertial force to the viscous force, while the Weissenberg number (Wi) describes the ratio of the elastic force to the viscous force.

$$
\begin{gathered}
R e=\frac{\rho V_{m} D_{h}}{\eta} \\
W i=\lambda \dot{\gamma}_{c}
\end{gathered}
$$

here, $\rho, V_{m}$, and $\dot{\gamma}_{c}$ denote the solution density, mean flow velocity, and characteristic shear rate, respectively. The relative effect of fluid elasticity on inertia can be estimated by the elasticity number $(E l)$.

$$
E l=\frac{W i}{R e}
$$

Table 1. Flow rates and the calculated non-dimensional numbers $(R e, W i$, and $E l)$ at different voltages

\begin{tabular}{|c|c|c|c|c|c|}
\hline $\begin{array}{c}\text { Flow } \\
\text { Resistance } \\
\left(\mathrm{Pa} \cdot \mathbf{s} \cdot \mathrm{m}^{-3}\right)\end{array}$ & $60 \mathrm{~V}$ & $100 \mathrm{~V}$ & $150 \mathrm{~V}$ & $200 \mathrm{~V}$ & $250 \mathrm{~V}$ \\
\hline $4.96 \times 10^{11}$ & $\begin{array}{c}Q=0.20 \\
R e=10.12 \\
W i=0.92 \\
E l=0.09\end{array}$ & $\begin{array}{c}Q=0.49 \\
R e=24.80 \\
W i=2.26 \\
E l=0.009\end{array}$ & $\begin{array}{c}Q=1.08 \\
\operatorname{Re}=54.66 \\
W i=5 \\
E l=0.09\end{array}$ & $\begin{array}{c}Q=1.64 \\
\operatorname{Re}=83.00 \\
W i=7.59 \\
E l=0.09\end{array}$ & $\begin{aligned} Q & =2.82 \\
R e & =142.7 \\
W i & =13.05 \\
E l & =0.09\end{aligned}$ \\
\hline $9.92 \times 10^{11}$ & $\begin{aligned} Q & =0.19 \\
R e & =9.61 \\
W i & =0.87 \\
E l & =0.09\end{aligned}$ & $\begin{array}{c}Q=0.27 \\
R e=13.66 \\
W i=1.25 \\
E l=0.09\end{array}$ & $\begin{array}{c}Q=0.44 \\
R e=22.26 \\
W i=2.03 \\
E l=0.09\end{array}$ & $\begin{array}{c}Q=0.72 \\
R e=36.44 \\
W i=3.33 \\
E l=0.09\end{array}$ & $\begin{array}{c}Q=1.01 \\
R e=51.11 \\
W i=4.67 \\
E l=0.09\end{array}$ \\
\hline $1.48 \times 10^{12}$ & $\begin{array}{c}Q=0.11 \\
R e=3.18 \\
W i=0.29 \\
E l=0.09\end{array}$ & $\begin{array}{c}Q=0.19 \\
R e=9.61 \\
W i=0.87 \\
E l=0.09\end{array}$ & $\begin{array}{c}Q=0.28 \\
\operatorname{Re}=14.17 \\
W i=1.29 \\
E l=0.09\end{array}$ & $\begin{array}{c}Q=0.42 \\
R e=21.25 \\
W i=1.94 \\
E l=0.09\end{array}$ & $\begin{array}{c}Q=0.59 \\
R e=29.86 \\
W i=2.73 \\
E l=0.09\end{array}$ \\
\hline
\end{tabular}
in the channels with different flow resistances at the fixed frequency of $40 \mathrm{~Hz}$. The unit of the flow rate $(Q)$ is $\mathrm{mL} / \mathrm{min}$.

To examine the effect of the applied voltages and channel lengths on the flow characteristics of $13 \mu \mathrm{m}$ particles (blockage ratio $\beta=0.21$ ), particle distributions in the microchannels with lengths of 1,2, and $3 \mathrm{~cm}$ were monitored. Figure 3 shows the stacked microscopic images of flow patterns of $13 \mu \mathrm{m}$ particles and normalized fluorescence intensities before the outlet trifurcation region of the microchannel. The fluorescence intensity was normalized to the highest intensity value under each flow condition.

In the microchannel with $1 \mathrm{~cm}$ length, $13 \mu \mathrm{m}$ particles were widely distributed near the center region at $60 \mathrm{~V}$. As the applied voltage increased, the flow rate generated by the piezoelectric pump increased, and the distribution of $13 \mu \mathrm{m}$ particles became narrower near the center as the elastic force increased. At $250 \mathrm{~V}(R e=142.7, W i=13.05), 13 \mu \mathrm{m}$ particles showed three fluorescent streamlines because of the increased inertial effect [35,36]. As the channel length increased, the values of non-dimensional numbers (Re and $\mathrm{Wi}$ ) decreased, which resulted in a reduced elastic force. However, owing to the sufficient channel length for particle focusing, $13 \mu \mathrm{m}$ particles migrated toward the center and focused tighter along the centerline. The lateral position of $13 \mu \mathrm{m}$ particles was saturated at the center at an applied voltage higher than $150 \mathrm{~V}$ in a $2 \mathrm{~cm}$ channel and $100 \mathrm{~V}$ in a $3 \mathrm{~cm}$ channel. To 
achieve the high-throughput and high-concentration factor in the closed-loop system, the channel length of the four parallel channel devices was selected as $2 \mathrm{~cm}$ for tight focusing of cells with minimized flow resistance.

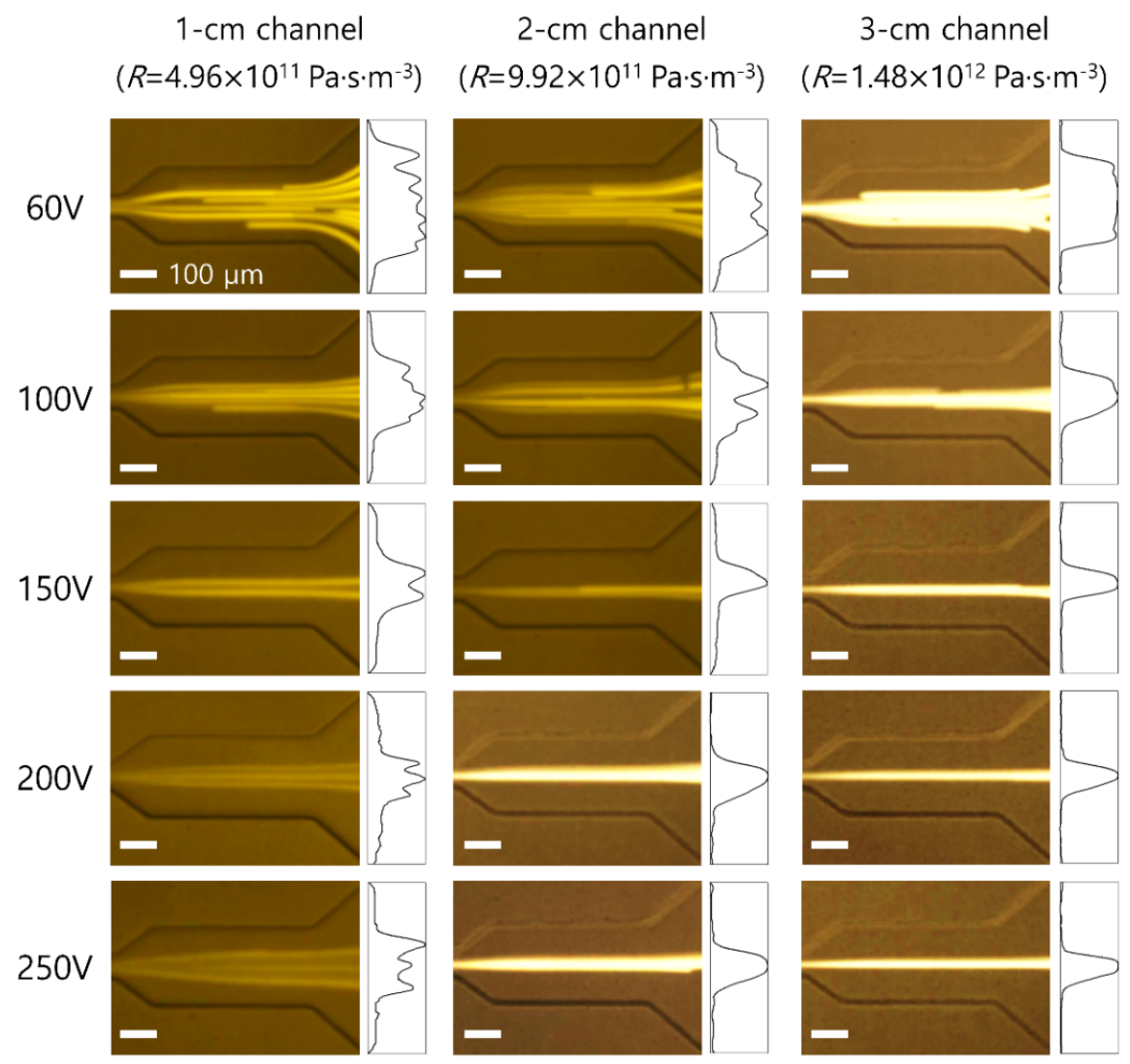

Figure 3. Stacked microscopic images (left) and normalized fluorescent intensity in an expansion region (right) of $13 \mu \mathrm{m}$ fluorescent particles at a fixed frequency $(40 \mathrm{~Hz})$ with different applied voltages of $60,100,150,200$, and $250 \mathrm{~V}$ in microchannels with different lengths of 1,2 , and $3 \mathrm{~cm}$, respectively. The scale bar is $100 \mu \mathrm{m}$.

For the lysed blood sample, the viscosity was dependent on the hematocrit of the blood sample. The viscosity of lysed blood samples with a normal range of hematocrit $(\sim 50 \%)$ is $\sim 2.4 \mathrm{cP}$, while the viscosity of lysed samples using packed red blood cells for blood transfusion ( $70 \%$ hematocrit) is $\sim 3 \mathrm{cP}$ [21]. Therefore, to confirm the capability of our parallel channel device to utilize the lysed blood samples with various hematocrits, an examination of the viscosity effect on the pumping performance using a piezoelectric pump was required. Figure 4a shows the viscosity-dependent flow rates generated by the piezoelectric pump at a fixed frequency of $40 \mathrm{~Hz}$ and a fixed applied voltage of $250 \mathrm{~V}$. Glycerol was diluted in water at various volume ratios to prepare glycerol aqueous solutions with different viscosities of 1,2,3, and $4 \mathrm{cP}$. As the sample viscosity increased, the flow rate decreased because of the increased flow resistance $\left(R \propto \eta, Q=\frac{\Delta P}{R} \propto \frac{1}{R}\right.$, $\Delta P$ is the pressure drop). Using the glycerol solution at $4 \mathrm{cP}$, the flow rate was measured as $\sim 0.6 \mathrm{~mL} / \mathrm{min}$. As the viscosity of the glycerol solution decreased to 3,2 , and $1 \mathrm{cP}$, the flow rates increased to $1,1.3$, and $1.8 \mathrm{~mL} / \mathrm{min}$, respectively. The flow rate is affected by the viscosity of the sample according to the relationship $y=2.15-0.38 x$. Therefore, even with a high-viscosity sample, for example, lysed sample using $70 \%$ hematocrit blood, the throughput of our four parallel channel device could be achieved at up to $\sim 1 \mathrm{~mL} / \mathrm{min}$ using a piezoelectric pump. 
(a)

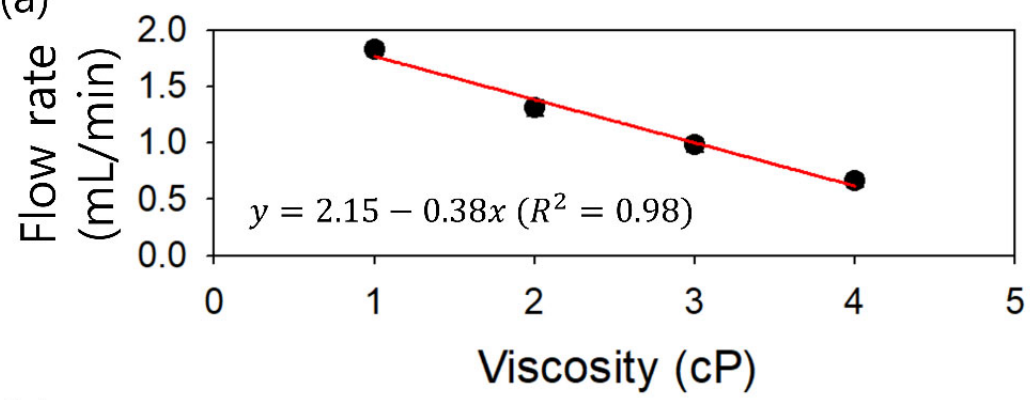

(b)

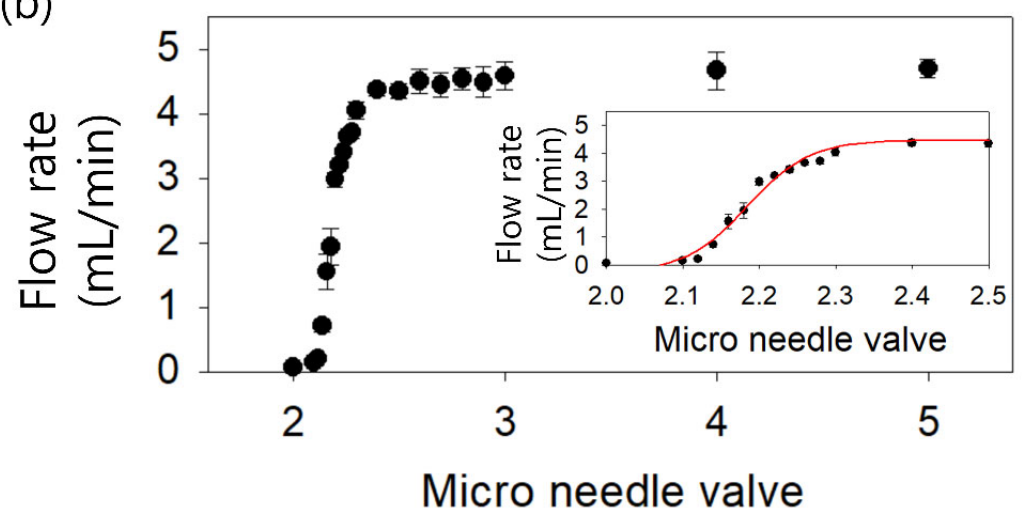

Figure 4. (a) Effect of viscosity on the generated flow rate from a PZT pump at a fixed frequency and applied voltage $(40 \mathrm{~Hz}, 250 \mathrm{~V})$. (b) Micro needle valve-based flow rate control at the fixed frequency and applied voltage $(40 \mathrm{~Hz}, 250 \mathrm{~V})$. An inset graph shows the flow rate using a micro needle valve ranging from 2.0 to 2.5 .

To compose the closed-loop system for a high concentration factor, the flow rate factor was adopted, which is the ratio of the inlet flow rate to the outlet flow rate at the side outlet (outlet B). Two piezoelectric pumps were used, which were modulated simultaneously by a single controller. A micro needle valve was additionally used at outlet $B$, which enabled more detailed flow rate control with the piezoelectric pump. Figure $4 \mathrm{~b}$ shows the flow rate reduced by the micro needle valve under the flow generated by the piezoelectric pump at a fixed frequency of $40 \mathrm{~Hz}$ and a fixed applied voltage of $250 \mathrm{~V}$. At valve scales higher than 2.3 , the micro needle valve was fully open, which had no effect on the flow resistance in the microchannel. The flow rate was saturated at approximately $4.5 \mathrm{~mL} / \mathrm{min}$. As the scale of the valve is reduced within 2.3, the flow resistance increases and the flow rate decreases, as shown in the inset of Figure $4 \mathrm{~b}$ according to the relationship of $y=-0.26+\frac{4.73}{1+e^{\frac{x-2.18}{0.04}}}$ $\left(R^{2}=0.98\right)$. Therefore, it can be applied to manipulate the suction flow rate at outlet $\mathrm{B}$.

For the application of the closed-loop system for continuous cell concentration, residual WBCs (rWBCs) in the packed red blood cells were used. The diameter of the WBCs was 9-15 $\mu \mathrm{m}$, which have the blockage ratio of $0.15 \leq \beta \leq 0.25$ [12,30]. The initial volume of the lysed blood sample with a hematocrit of $70 \%$ was $10 \mathrm{~mL}$, which was placed in the sample reservoir. Two piezoelectric pumps were operated simultaneously at $250 \mathrm{~V}$ and $40 \mathrm{~Hz}$, and the scale of the micro needle valve was set to 2.19 , which reduced the suction flow rate at outlet $\mathrm{B}$ by approximately $50 \%$. Based on the flow rate measurement in Figure 2, the flow rates for sample injection and suction at outlet $\mathrm{B}$ were $\sim 1$ and $\sim 0.5 \mathrm{~mL} / \mathrm{min}$, respectively, in a $2 \mathrm{~cm}$-long channel.

Figure 5a shows the time-dependent concentration of rWBCs in the single channel among the four parallel channels in the device. At the inlet, rWBCs were randomly injected into the microchannel. As soon as rWBCs flowed through the microchannel, the cells were focused at the center ( $\mathrm{T}=1 \mathrm{~min}$ in Figure $5 \mathrm{a}$ ). In the closed-loop system, the focused cells collected at the center outlet were sent back to the inlet through the sample reservoir, while the additional suspending medium was removed from the side outlets by suction. 
Therefore, the intensity and the width of the fluorescent stream became stronger and thicker, as the closed-loop system was operated for longer ( $T=10$ and $20 \mathrm{~min}$ in Figure 5a). Finally, after $20 \mathrm{~min}$ of the closed-loop concentration process, all samples in the sample reservoir were consumed, and the volume of the sample left in the tubing connections as the dead volume was approximately $160 \mu \mathrm{L}$.

(a)
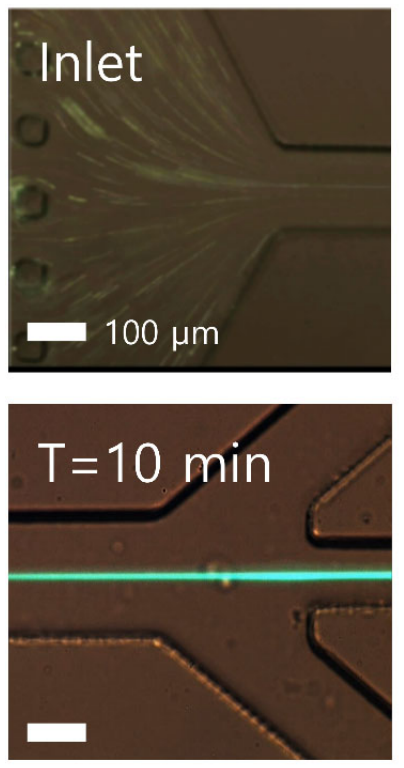

(b) Before concentration

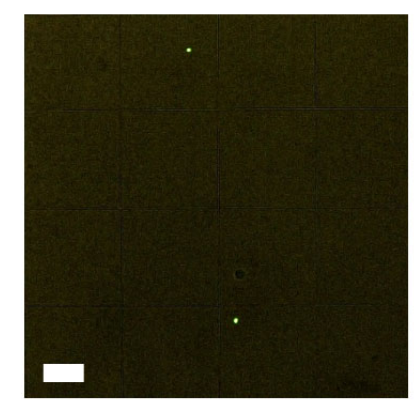

$1.8 \times 10^{3}$ cells $/ \mathrm{mL}$
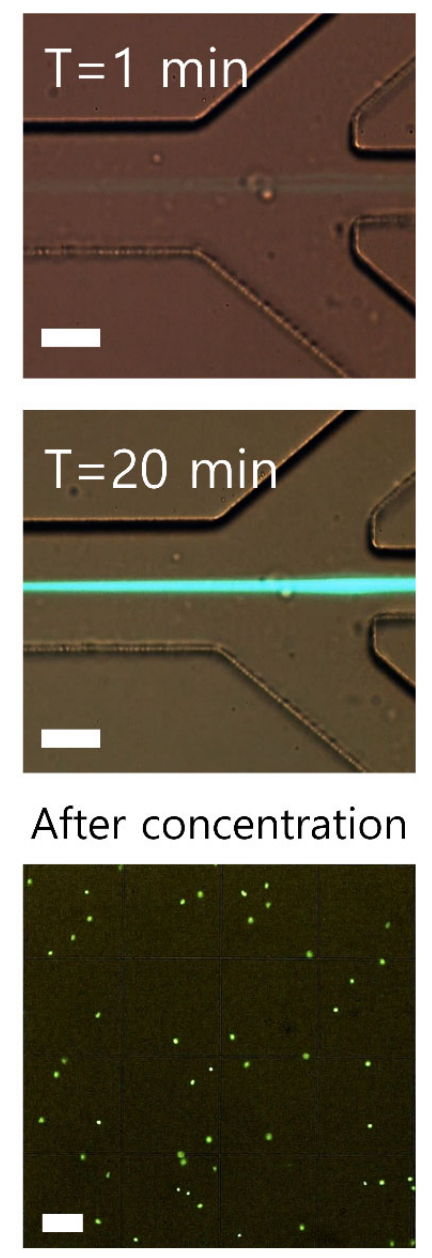

$1.12 \times 10^{5}$ cells $/ \mathrm{mL}$

Figure 5. Application of the closed-loop viscoelastic concentration system. (a) Time-dependent concentration of WBCs. Randomly injected WBCs in the hematocrit 70\% blood sample were tightly focused at the center and concentrated. (b) Fluorescent images of the sample before and after the closed-loop concentration process. The scale bar is $100 \mu \mathrm{m}$.

To evaluate the concentration increase of rWBCs, WBCs in the initial sample and the collected sample after the closed-loop concentration process were examined three times using a fluorescent microscope. The number of cells was counted using a hemocytometer three times, which were $1.78 \pm 0.18 \times 10^{3}$ cells $/ \mathrm{mL}$ in the initial sample and $1.13 \pm 0.13 \times 10^{5}$ cells $/ \mathrm{mL}$ in the final concentrated sample by $63.4 \pm 0.8$-fold. Figure $5 \mathrm{~b}$ shows an example of the sample before and after the closed-loop concentration process.

For a final demonstration, to expand the clinical usability of our closed-loop viscoelastic concentration system, prostate cancer cell line DU-145 cells were used in the urine sample using the same flow conditions in Figure 5. The viscosity of the urine sample was 0.8-1.0 cP at room temperature [37]. The flow rate generated in the microchannel by the piezoelectric pump was higher at the same applied voltage because the viscosity of the urine sample was approximately four times lower than that of the lysed blood sample at $70 \%$ hematocrit. According to the relationship $y=2.15-0.38 x$ shown in Figure $4 a$, the flow 
rates for sample injection and suction at outlet B were $\sim 1.8$ and $\sim 0.9 \mathrm{~mL} / \mathrm{min}$, respectively. Therefore, the required sample processing time decreased, that is, $\sim 11 \mathrm{~min}$ for a $10 \mathrm{~mL}$ urine sample.

Urine has the powerful advantage of being adopted for liquid biopsy, which is the non-invasive and patient-friendly collection of sufficient volume for analysis without a skilled medical professional. Before use, the size of DU-145 cells was determined, as shown in Figure 6a. The diameter of the DU-145 cells was $16.2 \pm 3.4 \mu \mathrm{m}$, which has a slightly larger blockage ratio of $0.16 \leq \beta \leq 0.45$ compared to WBCs.

(a)

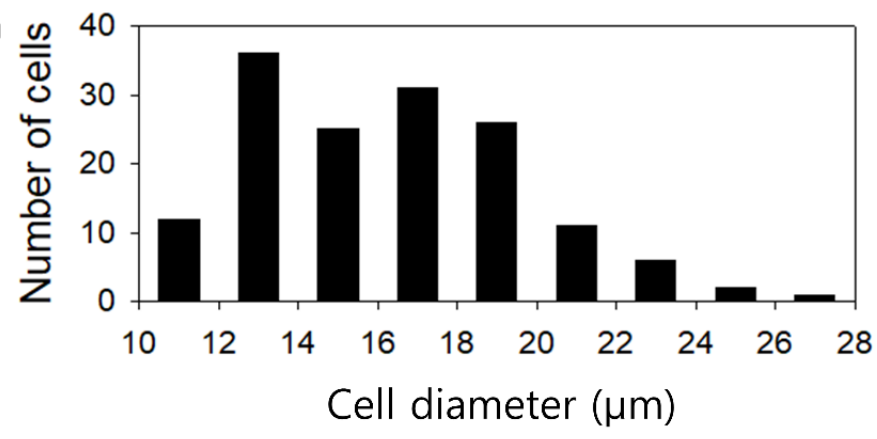

(b)
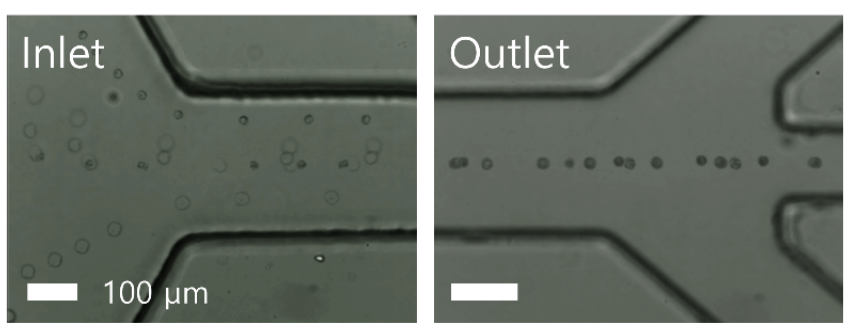

(c)

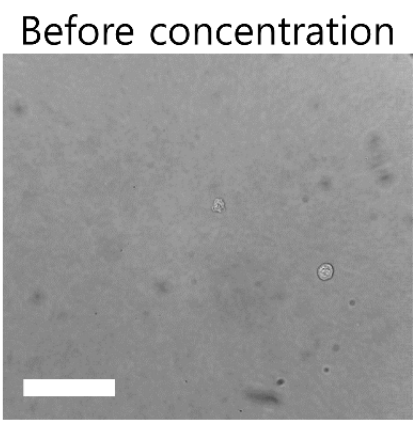

$1.5 \times 10^{3}$ cells $/ \mathrm{mL}$

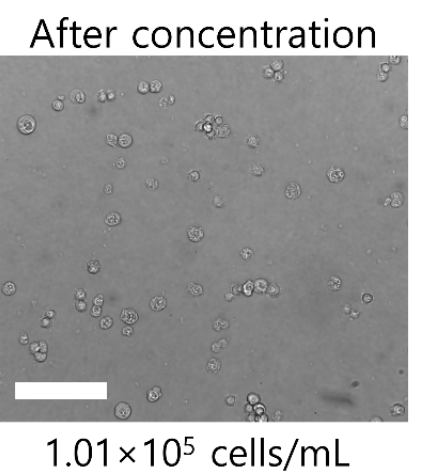

Figure 6. Application of the closed-loop system for the concentration of prostate cancer cells in urine samples. (a) Size distribution of DU-145 cells; $16.2 \pm 3.4 \mu \mathrm{m}$. (b) Stacked microscopic images during the concentration process of DU-145 cells. Randomly injected cells were tightly focused at the center in the outlet region. (c) Microscopic images of the sample before and after the closed-loop concentration process. The scale bar is $100 \mu \mathrm{m}$.

Figure $6 \mathrm{~b}$ shows the stacked microscopic images at the inlet and outlet of the microchannel during the concentration process of DU-145 cells, which were recorded with a high-speed camera. Due to two-dimensional focusing at the center plane, the image quality of cells at different channel heights could be compromised. At the inlet, DU-145 cells were randomly distributed across the microchannel. When flowing along the microchannel, the cells were affected by the viscoelastic force and tightly focused at the center. After $10 \mathrm{~min}$ of running in the closed-loop system, 10-mL of the initial sample in the sample reservoir was consumed and the number of DU-145 cells in the collected sample was enumerated, as shown in Figure 6c. The number of cells was $1.5 \times 10^{3}$ cells $/ \mathrm{mL}$ in the initial sample and $9.6 \times 10^{4}$ cells $/ \mathrm{mL}$ in the final concentrated sample, which showed a 64.1-fold increase. Meanwhile, based on the results, the main constituents of urine, including urea, creati- 
nine, sodium, potassium, and chloride, did not interrupt the viscoelasticity effect in the polymer solution.

\section{Discussion}

Using our device, cells can be concentrated without a costly and bulky centrifuge, which also can cause shear-induced cell damages [2,3]. Even cytospin, which is widely used for cell concentration and staining, can cause cells to appear distorted depending on the locations in the smear and the cell concentration [38,39]. In our device, mechanical shear forces induced in macro reservoirs and the tubing connection can be negligible. In addition, cells are focused at the microchannel center, where the shear rate is minimum in the microchannel [40]. Moreover, the most distinctive advantage of microchip-based cell concentration compared to centrifugation is integration with the on-chip post-analysis [41-43]. Therefore, our device is suitable for convenient sample preconcentration in clinical settings as benchtop equipment.

Our device can be used universally for cell concentration by modulating the channel width to meet the requirement of blockage ratio $(\beta \geq 0.1)$. In the microchannel used in this study, red blood cells, which are known as $\sim 6-8 \mu \mathrm{m}$, can be focused at the center of the channel, since the blockage ratio of red blood cells $(\beta=6 / 60)$ is higher than $0.1[44,45]$. Meanwhile, cells that cannot be tightly focused at the channel center also can be highly concentrated by modulating the suction flow rate ratio at the outlet [12].

Compared to previous closed-loop microfluidic devices [7,22,23], a bulky pumping instrument such as a peristaltic pump or a syringe pump is not required in our device, which enables benchtop equipment for clinical settings. In addition, due to the advantages of viscoelastic microfluidics $[10,11]$, viscoelastic cell concentration can be achieved in a simple rectangular straight channel without a complex channel design or external force field.

Even though the large volume $(10 \mathrm{~mL})$ of the sample was processed in this study, target cells in the small volume can be concentrated in our microfluidic device by integrating further microfluidic interfacing techniques [46-48] and micropump systems [49]. Additionally, easy integration with other microfluidic systems, for example, the microfluidic device for cell separation, enables continuous concentration after the separation process. This can be the distinctive characteristic in comparison with the centrifugation that requires a bulk tube-based batch process.

To enhance device performance, the concentration factor can be improved by reducing the dead volume in the tubing connection and fabricating a 3D-printed jig. The use of piezoelectric pumps enables easy integration with other fluidic parts, such as the microfluidic channel and the reservoirs as a fluidic module. Therefore, the closed-loop viscoelastic device provides a compact tool for high-throughput concentration to enhance the detection sensitivity of post-analysis in biomedical and clinical applications. Extremely rare cells, for example, WBCs in cerebrospinal fluid, CD34 (+) cells for stem cell transplantation, and circulating tumor cells (CTCs) for prognosis, can be concentrated and detected at high accuracy and sensitivity [50-53]. Moreover, the device throughput can be further enhanced by decreasing the flow resistance. Multiple channels in radial arrangement or stacked devices in multiple layers can be adopted to reduce the flow resistance $[54,55]$.

\section{Conclusions}

In summary, we developed a closed-loop continuous concentration system using minimized piezoelectric pumps. To reduce the flow resistance and enhance the device throughput, multiple parallel channels were designed in a single device. The effects of the applied voltage, frequency, and channel length on the piezoelectric pump-induced flow rate were evaluated. Based on the effects of the flow generation conditions, the flow characteristics of $13 \mu \mathrm{m}$ particles and WBCs were examined. In addition, the effects of the sample viscosity and the use of the micro needle valve were evaluated to verify the device's applicability. For clinical applications, WBC samples in packed RBC samples $(\sim 3 \mathrm{cP})$ were successfully concentrated with a high concentration ratio $(63.4 \pm 0.8$-fold $)$ within $20 \mathrm{~min}$. In addition, DU-145 prostate cancer cells spiked in urine samples could 
also be concentrated by $\sim 64.1$-fold within $\sim 11$ min due to the low viscosity $(0.8-1.0 \mathrm{cP})$ of urine compared to packed RBC blood samples. The proposed closed-loop system is highly applicable to various clinical evaluations, such as WBCs in cerebrospinal fluid, which should be fewer than five, and circulating tumor cells for cancer prognosis.

Author Contributions: Conceptualization, J.N.; methodology, J.N.; validation, J.K., H.L., and J.N.; formal analysis, J.K., H.L., and J.N.; investigation, H.L., H.J., S.C., and M.Y.; resources, J.N.; data curation, J.K., H.L., S.P., K.L., H.P., and J.N.; writing—original draft preparation, J.K., H.L., and J.N.; writing - review and editing, J.N.; visualization, J.K. and H.L.; supervision, C.L. and J.N.; project administration, C.L. and J.N.; funding acquisition C.L. and J.N. All authors have read and agreed to the published version of the manuscript.

Funding: This research was funded by the Korean government (MSIT), grant number 2020R1A2C 1014460; and the Ministry of Health and Welfare, Republic of Korea, grant number HR20C0021.

Data Availability Statement: Not applicable.

Acknowledgments: This work was supported by the National Research Foundation of Korea (NRF) grant funded by the Korean government (MSIT) (No. 2020R1A2C1014460). This research was supported by a grant of the Korea Health Technology R\&D Project through the Korea Health Industry Development Institute (KHIDI), funded by the Ministry of Health and Welfare, Republic of Korea (grant number: HR20C0021).

Conflicts of Interest: The authors declare no conflict of interest.

\section{References}

1. Warrick, J.; Casavant, B.; Frisk, M.; Beebe, D. A Microfluidic Cell Concentrator. Anal. Chem. 2010, 82, 8320-8326. [CrossRef]

2. Wang, D.I.C.; Sinskey, T.J.; Gerner, R.E.; De Filippi, R.P. Effect of centrifugation on the viability of Burkitt lymphoma cells. Biotechnol. Bioeng. 1968, 10, 641-649. [CrossRef]

3. Yang, J.; Hooper, W.C.; Phillips, D.J.; Tondella, M.L.; Talkington, D.F. Centrifugation of Human Lung Epithelial Carcinoma A549 Cells Up-Regulates Interleukin-1 $\beta$ Gene Expression. Clin. Vaccine Immunol. 2002, 9, 1142-1143. [CrossRef] [PubMed]

4. Dürr, M.; Kentsch, J.; Müller, T.; Schnelle, T.; Stelzle, M. Microdevices for manipulation and accumulation of micro-and nanoparticles by dielectrophoresis. Electrophoresis 2002, 24, 722-731. [CrossRef]

5. Zhu, J.; Xuan, X. Dielectrophoretic focusing of particles in a microchannel constriction using DC-biased AC flectric fields. Electrophoresis 2009, 30, 2668-2675. [CrossRef]

6. Chen, Y.; Li, S.; Gu, Y.; Li, P.; Ding, X.; Wang, L.; McCoy, J.P.; Levine, S.J.; Huang, T.J. Continuous enrichment of low-abundance cell samples using standing surface acoustic waves (SSAW). Lab Chip 2014, 14, 924-930. [CrossRef] [PubMed]

7. Jakobsson, O.; Oh, S.S.; Antfolk, M.; Eisenstein, M.; Laurell, T.; Soh, H.T. Thousand-Fold Volumetric Concentration of Live Cells with a Recirculating Acoustofluidic Device. Anal. Chem. 2015, 87, 8497-8502. [CrossRef]

8. Zalis, M.C.; Reyes, J.F.; Augustsson, P.; Holmqvist, S.; Roybon, L.; Laurell, T.; Deierborg, T. Label-free concentration of viable neurons, hESCs and cancer cells by means of acoustophoresis. Integr. Biol. 2016, 8, 332-340. [CrossRef]

9. Yamada, M.; Seki, M. Hydrodynamic filtration for on-chip particle concentration and classification utilizing microfluidics. Lab Chip 2005, 5, 1233-1239. [CrossRef] [PubMed]

10. D'Avino, G.; Maffettone, P.; Greco, F.; Hulsen, M. Viscoelasticity-induced migration of a rigid sphere in confined shear flow. J. Non-Newton. Fluid Mech. 2010, 165, 466-474. [CrossRef]

11. Leshansky, A.M.; Bransky, A.; Korin, N.; Dinnar, U. Tunable nonlinear viscoelastic "focusing" in a microfluidic device. Phys. Rev. Lett. 2007, 98, 234501. [CrossRef]

12. Nam, J.; Jang, W.S.; Hong, D.H.; Lim, C.S. Viscoelastic Separation and Concentration of Fungi from Blood for Highly Sensitive Molecular Diagnostics. Sci. Rep. 2019, 9, 1-12. [CrossRef]

13. Kim, B.; Kim, J.M. Elasto-inertial particle focusing under the viscoelastic flow of DNA solution in a square channel. Biomicrofluidics 2016, 10, 024111. [CrossRef]

14. Liu, C.; Xue, C.; Hu, G. Sheathless separation of particles and cells by viscoelastic effects in straight rectangular micro-channels. Procedia Eng. 2015, 126, 721-724. [CrossRef]

15. Liu, C.; Guoqing, H.; Tian, F.; Yang, N.; Yanping, D.; Ding, Y.; Wei, J.; Hu, G.; Nie, G.; Sun, J. Field-Free Isolation of Exosomes from Extracellular Vesicles by Microfluidic Viscoelastic Flows. ACS Nano 2017, 11, 6968-6976. [CrossRef] [PubMed]

16. Nam, J.; Lim, H.; Kim, D.; Jung, H.; Shin, S. Continuous separation of microparticles in a microfluidic channel via the elasto-inertial effect of non-Newtonian fluid. Lab Chip 2012, 12, 1347-1354. [CrossRef] [PubMed]

17. Nam, J.; Namgung, B.; Lim, C.T.; Bae, J.-E.; Leo, H.L.; Cho, K.S.; Kim, S. Microfluidic device for sheathless particle focusing and separation using a viscoelastic fluid. J. Chromatogr. A 2015, 1406, 244-250. [CrossRef] [PubMed] 
18. Nam, J.; Shin, Y.; Tan, J.K.S.; Lim, Y.B.; Lim, C.T.; Kim, S. High-throughput malaria parasite separation using a viscoelastic fluid for ultrasensitive PCR detection. Lab Chip 2016, 16, 2086-2092. [CrossRef]

19. Nam, J.; Tan, J.; Khoo, B.L.; Namgung, B.; Leo, H.L.; Lim, C.T.; Kim, S. Hybrid capillary-inserted microfluidic device for sheathless particle focusing and separation in viscoelastic flow. Biomicrofluidics 2015, 9, 064117. [CrossRef] [PubMed]

20. Nam, J.; Jee, H.; Jang, W.S.; Yoon, J.; Park, B.G.; Lee, S.J.; Lim, C.S. Sheathless Shape-Based Separation of Candida Albicans Using a Viscoelastic Non-Newtonian Fluid. Micromachines 2019, 10, 817. [CrossRef]

21. Nam, J.; Jang, W.S.; Lim, C.S. Non-electrical powered continuous cell concentration for enumeration of residual white blood cells in WBC-depleted blood using a viscoelastic fluid. Talanta 2019, 197, 12-19. [CrossRef]

22. Choi, K.; Ryu, H.; Siddle, K.J.; Piantadosi, A.; Freimark, L.; Park, D.J.; Sabeti, P.; Han, J. Negative Selection by Spiral Inertial Microfluidics Improves Viral Recovery and Sequencing from Blood. Anal. Chem. 2018, 90, 4657-4662. [CrossRef] [PubMed]

23. Ryu, H.; Choi, K.; Qu, Y.; Kwon, T.; Lee, J.; Han, J. Patient-Derived Airway Secretion Dissociation Technique to Isolate and Concentrate Immune Cells Using Closed-Loop Inertial Microfluidics. Anal. Chem. 2017, 89, 5549-5556. [CrossRef]

24. Mu, C.; Zhang, Z.; Lin, M.; Dai, Z.; Cao, X. Development of a highly effective multi-stage surface acoustic wave SU-8 microfluidic concentrator. Sens. Actuators B Chem. 2015, 215, 77-85. [CrossRef]

25. Li, Z.; Mak, S.Y.; Sauret, A.; Shum, H.C. Syringe-pump-induced fluctuation in all-aqueous microfluidic system implications for flow rate accuracy. Lab Chip 2014, 14, 744-749. [CrossRef]

26. Yobas, L.; Tang, K.-C.; Yong, S.-E.; Ong, E.K.-Z. A disposable planar peristaltic pump for lab-on-a-chip. Lab Chip 2008, 8, 660-662. [CrossRef]

27. Zhao, B.; Cui, X.; Ren, W.; Xu, F.; Liu, M.; Ye, Z.-G. A Controllable and Integrated Pump-enabled Microfluidic Chip and Its Application in Droplets Generating. Sci. Rep. 2017, 7, 1-8. [CrossRef]

28. Cazorla, P.-H.; Fuchs, O.; Cochet, M.; Maubert, S.; Le Rhun, G.; Robert, P.; Fouillet, Y.; Defay, E. Piezoelectric Micro-pump with PZT Thin Film for Low Consumption Microfluidic Devices. Procedia Eng. 2014, 87, 488-491. [CrossRef]

29. Guan, Y. Guan Performance Analysis of a Microfluidic Pump Based on Combined Actuation of the Piezoelectric Effect and Liquid Crystal Backflow Effect. Micromachines 2019, 10, 584. [CrossRef]

30. Lim, H.; Back, S.M.; Hwang, M.H.; Lee, D.-H.; Choi, H.; Nam, J. Sheathless High-Throughput Circulating Tumor Cell Separation Using Viscoelastic non-Newtonian Fluid. Micromachines 2019, 10, 462. [CrossRef]

31. Trenkle, F.; Haeberle, S.; Zengerle, R. Normally-closed peristaltic micropump with re-usable actuator and disposable fluidic chip. Procedia Chem. 2009, 1, 1515-1518. [CrossRef]

32. Seo, K.W.; Byeon, H.J.; Huh, H.K.; Lee, S.J. Particle migration and single-line particle focusing in microscale pipe flow of viscoelastic fluids. RSC Adv. 2014, 4, 3512-3520. [CrossRef]

33. Tehrani, M.A. An experimental study of particle migration in pipe flow of viscoelastic fluids. J. Rheol. 1996, 40, 1057-1077. [CrossRef]

34. Kim, B.; You, D.; Kim, Y.-J.; Oh, I.; Choi, S. Motorized smart pipette for handheld operation of a microfluidic blood plasma separator. Sens. Actuators B Chem. 2018, 267, 581-588. [CrossRef]

35. Zhou, J.; Giridhar, P.V.; Kasper, S.; Papautsky, I. Modulation of aspect ratio for complete separation in an inertial microfluidic channel. Lab Chip 2013, 13, 1919-1929. [CrossRef] [PubMed]

36. Zhou, J.; Papautsky, I. Fundamentals of inertial focusing in microchannels. Lab Chip 2013, 13, 1121-1132. [CrossRef] [PubMed]

37. Inman, B.A.; Etienne, W.; Rubin, R.; Owusu, R.A.; Oliveira, T.R.; Rodriques, D.B.; Maccarini, P.F.; Stauffer, P.R.; Mashal, A.; Dewhirst, M.W. The impact of temperature and urinary constituents on urine viscosity and its relevance to bladder hyper-thermia treatment. Int. J. Hyperth. 2013, 29, 206-210. [CrossRef]

38. Brunzel, N.A. Body Fluid Analysis: Manual Hemocytometer Counts and Differential Slide Preparation. In Fundamentals of Urine and Body Fluid Analysis, 4th ed.; Elsevier Health Sciences: Amsterdam, The Netherlands, 2016.

39. Harmening, D. Body Fluid Examination: The Qualitative, Quantitative, and Morphologic Analysis of Serous, Cerebrospinal, and Synovial Fluids. In Clinical Hematology and Fundamentals of Hemostasis, 5th ed.; F. A. Davis Company: Philadelphia, PA, USA, 2009.

40. Nam, J.; Lim, H.; Kim, D.; Shin, S. Separation of platelets from whole blood using standing surface acoustic waves in a microchannel. Lab Chip 2011, 11, 3361-3364. [CrossRef]

41. Parks, J.W.; Olson, M.A.; Kim, J.; Ozcelik, D.; Cai, H.; Carrion, R.; Patterson, J.L.; Mathies, R.A.; Hawkins, A.R.; Schmidt, H. Integration of programmable microfluidics and on-chip fluorescence detection for biosensing applications. Biomicrofluidics 2014, 8, 054111. [CrossRef]

42. Zhao, Y.; Li, Q.; Hu, X.; Lo, Y. Microfluidic cytometers with integrated on-chip optical systems for red blood cell and platelet counting. Biomicrofluidics 2016, 10, 064119. [CrossRef]

43. Chen, Y.-S.; Ma, Y.-D.; Chen, C.; Shiesh, S.-C.; Lee, G.-B. An integrated microfluidic system for on-chip enrichment and quantification of circulating extracellular vesicles from whole blood. Lab Chip 2019, 19, 3305-3315. [CrossRef] [PubMed]

44. Reichel, F.; Mauer, J.; Nawaz, A.A.; Gompper, G.; Guck, J.; Fedosov, D.A. High-Throughput Microfluidic Characterization of Erythrocyte Shapes and Mechanical Variability. Biophys. J. 2019, 117, 14-24. [CrossRef] [PubMed]

45. Pinho, D.; Muñoz-Sánchez, B.; Anes, C.; Vega, E.; Lima, R. Flexible PDMS microparticles to mimic RBCs in blood particulate analogue fluids. Mech. Res. Commun. 2019, 100, 103399. [CrossRef]

46. Fredrickson, C.K.; Fan, Z.H. Macro-to-micro interfaces for microfluidic devices. Lab Chip 2004, 4, 526-533. [CrossRef] 
47. Han, S.I. Microfluidic Interface Technology Based on Stereolithography for Glass-Based Lab-on-a-Chips. In Microfluidic Diagnostics: Methods and Protocols; Jenkins, G., Mansfield, C.D., Eds.; Springer: New York, NY, USA, 2013; pp. 169-184.

48. Pfreundt, A.; Andersen, K.B.; Dimaki, M.; E Svendsen, W. An easy-to-use microfluidic interconnection system to create quick and reversibly interfaced simple microfluidic devices. J. Micromech. Microeng. 2015, 25, 115010. [CrossRef]

49. Wang, Y.-N.; Fu, L.-M. Micropumps and biomedical applications-A review. Microelectron. Eng. 2018, 195, 121-138. [CrossRef]

50. Menaker, J.; Martin, I.B.K.; Hirshon, J.M. Marked elevation of cerebrospinal fluid white blood cell count: An unusual case of Streptococcus pneumoniae meningitis, differential diagnosis, and a brief review of current epidemiology and treatment recommendations. J. Emerg. Med. 2005, 29, 37-41. [CrossRef]

51. Neumann, B.; Steinberg, T.; Lee, D.-H.; Kress, J.; Kufner, M.; Schlachetzki, F.; Weinfurtner, G.; Linker, R.; Angstwurm, K. Reactive increase of cerebrospinal fluid white blood cell count after lumbar puncture: Fact or fiction? J. Neurol. Sci. 2020, 414, 116876. [CrossRef]

52. Allan, D.; Keeney, M.; Howson-Jan, K.; Popma, J.; Weir, K.; Bhatia, M.; Sutherland, D.R.; Chin-Yee, I.H.; Allan, D. Number of viable CD34+ cells reinfused predicts engraftment in autologous hematopoietic stem cell transplantation. Bone Marrow Transplant. 2002, 29, 967-972. [CrossRef]

53. Liang, W.; Liu, J.; Yang, X.; Zhang, Q.; Yang, W.; Zhang, H.; Liu, L. Microfluidic-based cancer cell separation using active and passive mechanisms. Microfluid. Nanofluid. 2020, 24, 1-19. [CrossRef]

54. Khoo, B.L.; Warkiani, M.E.; Tan, D.S.-W.; Bhagat, A.A.S.; Irwin, D.; Lau, D.P.; Lim, A.S.T.; Lim, K.H.; Krisna, S.S.; Lim, W.-T.; et al. Clinical Validation of an Ultra High-Throughput Spiral Microfluidics for the Detection and Enrichment of Viable Circulating Tumor Cells. PLoS ONE 2014, 9, e99409. [CrossRef]

55. Warkiani, M.E.; Khoo, B.L.; Tan, D.S.-W.; Bhagat, A.A.S.; Lim, W.-T.; Yap, Y.S.; Lee, S.C.; Soo, R.A.; Han, J.; Lim, C.T. An ultra-high-throughput spiral microfluidic biochip for the enrichment of circulating tumor cells. Analyst 2014, 139, 3245-3255. [CrossRef] [PubMed] 